\title{
INFLUENCES OF RIDGE WIDTH AND INTERCROPPING ONION WITH FABA BEAN ON BULB YIELD AND COMEPTITIVE RELATIONSHIPS
}

\author{
El Refaey R.A. ${ }^{1}$, U.A. Abd El Razek ${ }^{1}$, M.N. Sherief ${ }^{2}$ and Manal A.K.Z. Shehata ${ }^{2}$ \\ ${ }^{1}$ Agronomy Department, Faculty of Agriculture, Tanta University, Egypt. \\ ${ }^{2}$ Crop Intensification Research Department, Field Crops Research Institute, A.R.C., Giza, Egypt.
}

\section{ABSTRACT}

$\mathrm{T}$ The study was carried out during the two successive seasons of 2013/14 and 2014/15 at the farm of Sers El-Lyan Agricultural Research Station, Agricultural Research Center, El - Menofiya Governorate, Egypt to identify and assess the suitable pattern of intercropping onion with faba bean for increasing land usage and profitability of farmers. The treatments between three ridge widths $(60,90$ and $120 \mathrm{~cm})$ and ten cropping systems $(100 \%$ faba bean $+27 \%$ onion, $100 \%$ faba bean $+33 \%$ onion, $100 \%$ faba bean $+41 \%$ onion, $100 \%$ faba bean $+55 \%$ onion, sole faba bean 'recommended', sole faba bean 'I', sole faba bean 'II', sole onion 'recommended', sole onion 'I' and sole onion 'II') were studied. The experimental layout was conducted in split plot design with three replications by allocating the ridge widths in the main- plots and cropping systems in the sub-plots. Sub-plot area consisted of (12 ridges- $60 \mathrm{~cm}$ width or 8 ridges- $-90 \mathrm{~cm}$ width and 6 ridges $-120 \mathrm{~cm}$ apart) and 3 meters long. The results showed that' higher bulb diameter was obtained, followed by 90 $\mathrm{cm}$ ridge width. On the other hand, the closest ridge width gave the lowest bulb diameter. The highest total weight of the plant, average bulb weight and bulbs yield/fad were obtained under the widest ridge width, followed by $90 \mathrm{~cm}$ ridge width. Sole onion had the highest number of leaves per plant, bulbs length and diameter, total weight of the plant, bulb weight and blubs yield per fad compared to those of intercropping patterns. The maximum number of leaves per plant, bulbs length and diameter, total weight of the plant and bulb weight were obtained by intercropping pattern $100 \%$ faba bean $+27 \%$ onion; Meanwhile' the highest bulbs yield per fad was recorded by intercropping pattern $100 \%$ faba bean $+55 \%$ onion. The interaction between ridge widths and cropping systems was significant for most onion traits. Maximum relative yield of onion and land equivalent ratio were obtained by intercropping pattern $100 \%$ faba bean $+55 \%$ onion of ridge width $120 \mathrm{~cm}$. On the other side, maximum relative crowding coefficient (RCC) was obtained by intercropping pattern $100 \%$ faba bean $+27 \%$ onion of ridge width $120 \mathrm{~cm}$. The results indicate that' the value of aggressivity of faba bean was positive for all treatments, while, the values of aggressivity were negative for all intercropped onion with faba bean in both seasons. Intercropping pattern $100 \%$ faba bean $+55 \%$ onion of ridge width $120 \mathrm{~cm}$ achieved the highest bulbs yield and economic return.

Keywords: Ridge width, Intercropping, faba bean, onion, competitive relationships, economic return

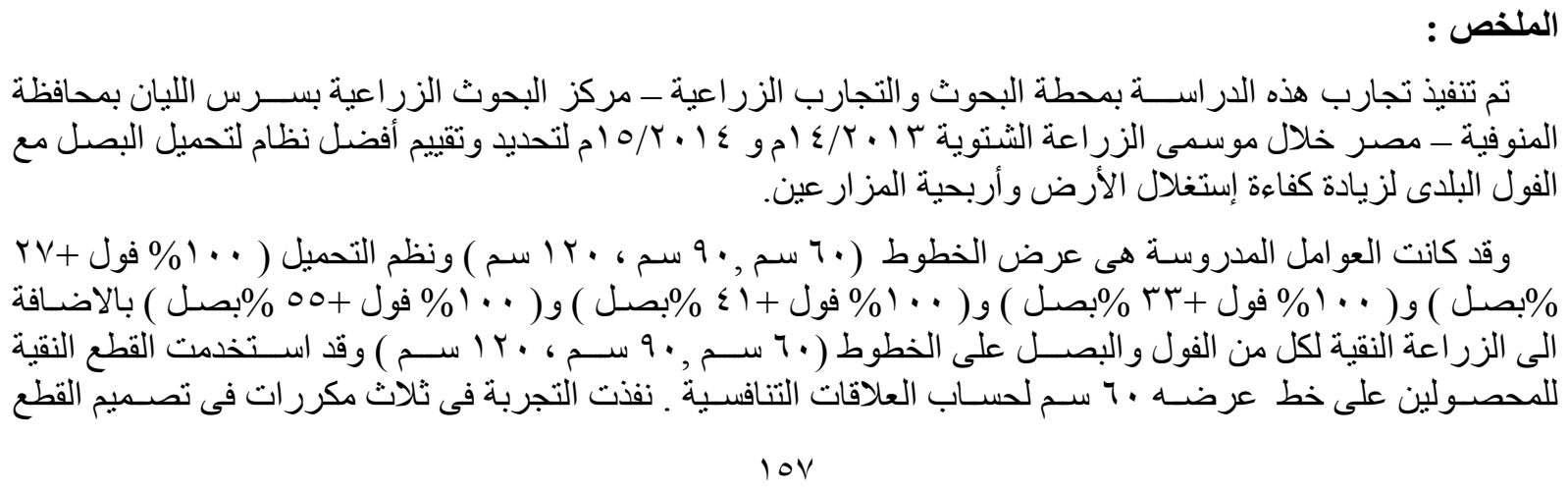




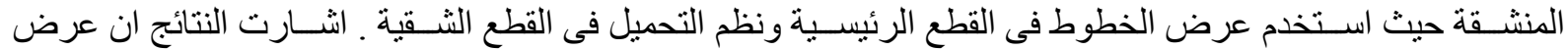

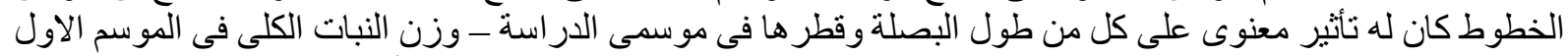

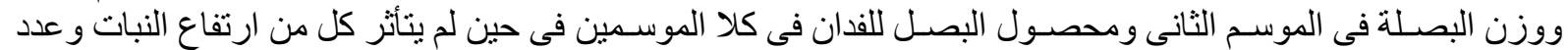

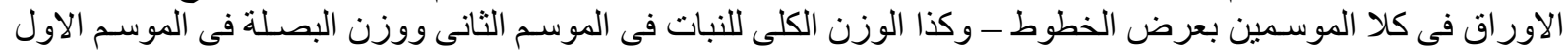

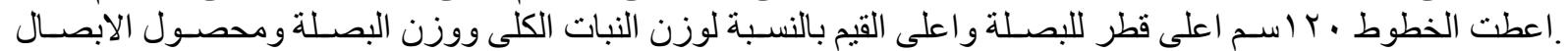

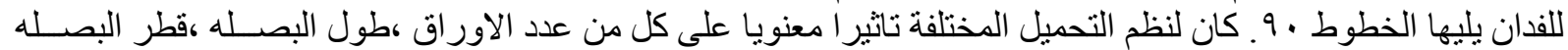

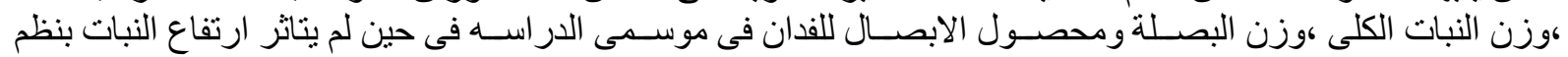

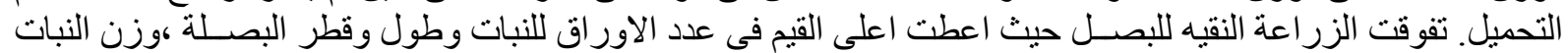

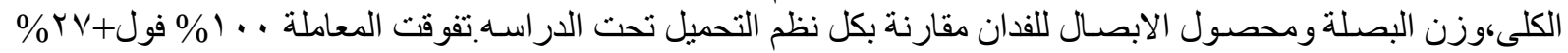

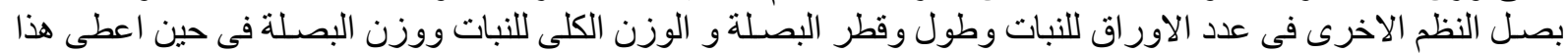

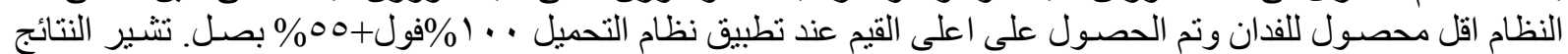

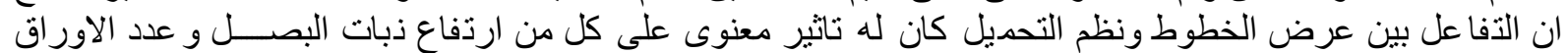

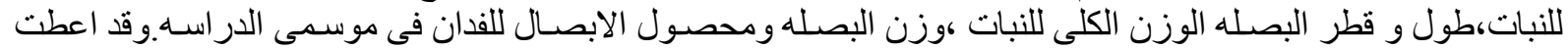

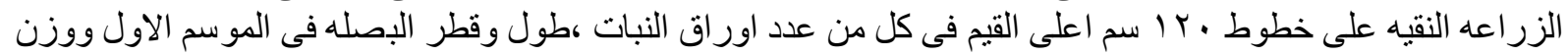

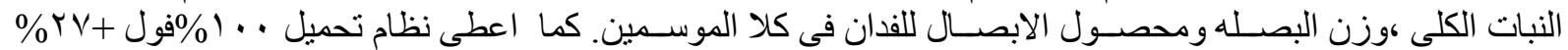

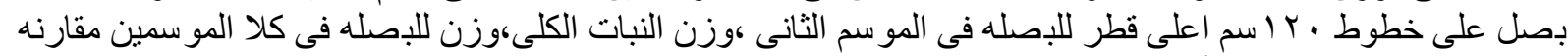

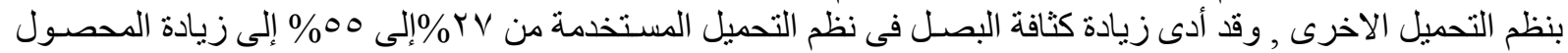

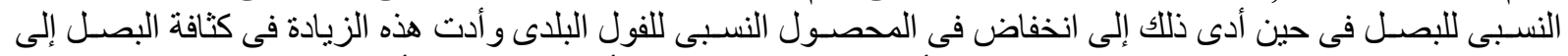

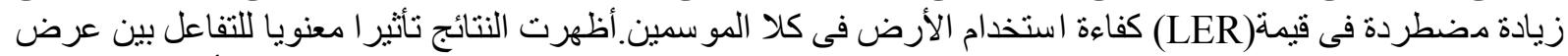

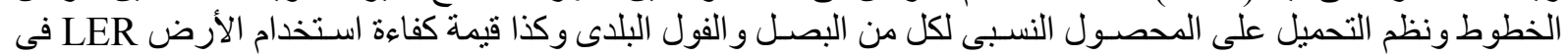

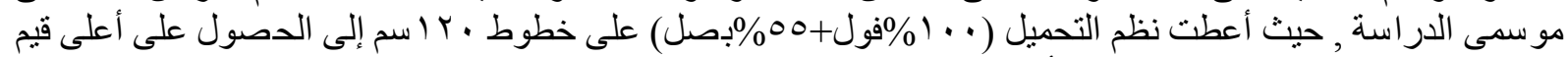

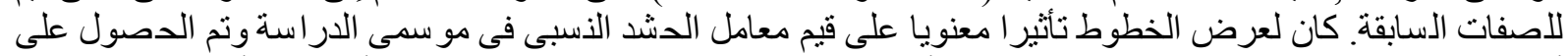

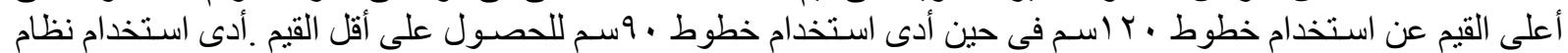

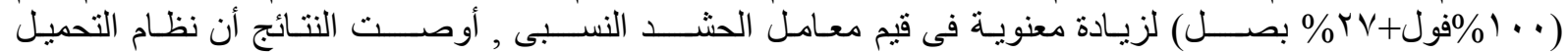

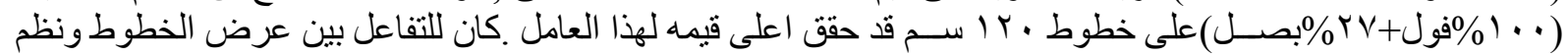

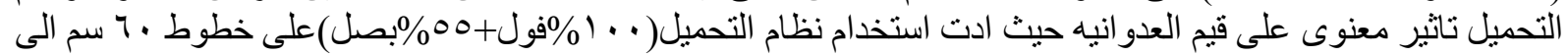

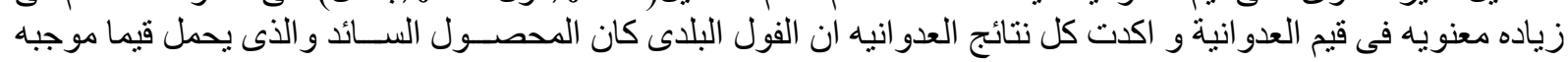

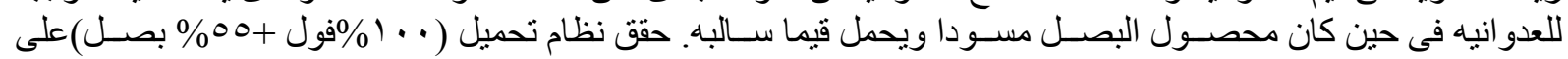

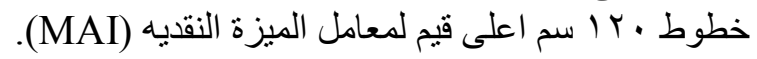

\section{INTERODUCTION}

In Egypt, the low size of cultivated land per farmer is the one of the most problems associated with cropping system. So, output improvement in a crop production system must be related to the better use of resources. Proper cropping system could be ensured optimum plant growth through adequate utilization of moisture, light, spacing and nutrients. Intercropping as a cash field crop such as onion (Allium cepa L.) with faba bean (Vicia faba L.) could be appropriate agronomic practice for increasing land use efficiency and farmer's benefit in the Nile Valley and Delta areas. It is known that' onion is one of the most important vegetable crops grown worldwide with 57.9 million tons produced annually (USDA, 2005). Onion has been reported to be rich in phytochemicals especially medicinal flavonols (Javadzadeh et al., 2009).

However, El-Hawary et al. (1991) showed that although intercropping onion with faba bean decreased yield of the both crops, but all intercropping treatments gave better financial returns than either crop grown alone. Also, Ghobashi and El-Aweel (1996) found that' land equivalent ratio was greater than one in intercropping of onion with faba bean compared with the sole cultures. Accordingly, it is expected that a suitable spatial arrangement of intercropping onion with faba bean could be affected by ridge width.

Certainly, ridge width have important role in sole culture, which in turn determines the area available to individual plant. The response of sole faba bean to ridge width and plant density 
indicated that there was a wide range of densities are commonly used (Bianchi, 1979; Ageeb, 1983; Caballero, 1987; Pilbeam et al., 1991; Almeida et al., 1995; Loss et al., 1998; LópezBellido et al., 2005; Mathews et al., 2008; Khalil et al, 2010; Ragab et al., 2010 and Abd ElRahman, 2014). With respect to onion crop, Khan et al. (2003) mentioned that' the productivity of onion crop is strongly influenced by a number of environmental factors including the cultural practices such as plant density. Also, Dorcas et al. (2012) reported that' increasing plant density of onion from 100,000 to 500,000 plants $\mathrm{ha}^{-1}$ decreased average bulb weight and bulb diameter from $58.22 \mathrm{~g}$ to $40.04 \mathrm{~g}$ and $4.56 \mathrm{~cm}$ to $2.83 \mathrm{~cm}$, respectively. Thus, the main target of this study was to identify and assess the suitable pattern of intercropping onion with faba bean for increasing land usage and profitability of farmers.

\section{MATERIALS AND METHODS}

The present investigation was carried out during the two successive seasons of 2013/14 and 2014/15 at the farm of Sers El-Lyan Agricultural Research Station, Agricultural Research Center, El - Menofiya Governorate, Egypt. The aim of the present investigation was to identify and assess the suitable pattern of intercropping onion with faba bean for increasing land usage and profitability of farmers. The treatments were the combinations between ridge widths and cropping systems as follows:

1. Growing two sides of ridge with faba bean plants ( 2 plants/hill spaced at $25 \mathrm{~cm}$ apart) on a ridge of $60 \mathrm{~cm}$ width. This pattern was expressed as sole faba bean (recommended).

2. Growing three rows of onion transplants spaced at $10 \mathrm{~cm}$ apart in the upper of ridge of 60 $\mathrm{cm}$ width. This pattern was expressed as sole onion (recommended).

3. Growing two sides of ridge with faba bean plants ( 2 plants/hill spaced at $25 \mathrm{~cm}$ apart) on a ridge of $60 \mathrm{~cm}$ width, besides growing one row of onion transplants spaced at $12 \mathrm{~cm}$ apart on the middle of the ridge. This pattern was expressed as $100 \%$ faba bean $+27 \%$ onion.

4. Growing two sides of ridge with faba bean plants ( 2 plants/hill spaced at $25 \mathrm{~cm}$ apart) on a ridge of $60 \mathrm{~cm}$ width, besides growing one row of onion transplants spaced at $10 \mathrm{~cm}$ apart on the middle of the ridge. This pattern was expressed as $100 \%$ faba bean $+33 \%$ onion.

5. Growing two sides of ridge with faba bean plants ( 2 plants/hill spaced at $25 \mathrm{~cm}$ apart) on a ridge of $60 \mathrm{~cm}$ width, besides growing one row of onion transplants spaced at $8 \mathrm{~cm}$ apart on the middle of the ridge. This pattern was expressed as $100 \%$ faba bean $+41 \%$ onion.

6. Growing two sides of ridge with faba bean plants ( 2 plants/hill spaced at $25 \mathrm{~cm}$ apart) on a ridge of $60 \mathrm{~cm}$ width, besides growing one row of onion transplants spaced at $6 \mathrm{~cm}$ apart on the middle of the ridge. This pattern was expressed as $100 \%$ faba bean $+55 \%$ onion.

7. Growing three rows of faba bean plants on one ridge ( 2 plants/hill spaced at $25 \mathrm{~cm}$ apart) on a ridge of $90 \mathrm{~cm}$ width. This pattern was expressed as sole faba bean (I).

8. Growing four rows of onion plants on one ridge transplants spaced at $9 \mathrm{~cm}$ apart in ridge of $90 \mathrm{~cm}$ width. This pattern was expressed as sole onion (I).

9. Growing three rows of faba bean plants on one ridge ( 2 plants/hill spaced at $25 \mathrm{~cm}$ apart) on a ridge of $90 \mathrm{~cm}$ width, besides growing one row of onion transplants spaced at $8 \mathrm{~cm}$ apart in the same ridge. This pattern was expressed as $100 \%$ faba bean $+27 \%$ onion.

10. Growing three rows of faba bean plants on one ridge (2 plants/hill spaced at $25 \mathrm{~cm}$ apart) on a ridge of $90 \mathrm{~cm}$ width, besides growing one row of onion transplants spaced at $6.6 \mathrm{~cm}$ apart in the same ridge. This pattern was expressed as $100 \%$ faba bean $+33 \%$ onion. 
11. Growing three rows of faba bean plants on one ridge (2 plants/hill spaced at $25 \mathrm{~cm}$ apart) on a ridge of $90 \mathrm{~cm}$ width, besides growing two rows of onion transplants spaced at $10.6 \mathrm{~cm}$ apart in the same ridge. This pattern was expressed as $100 \%$ faba bean $+41 \%$ onion.

12. Growing three rows of faba bean plants on one ridge ( 2 plants/hill spaced at $25 \mathrm{~cm}$ apart) on a ridge of $90 \mathrm{~cm}$ width, besides growing two rows of onion transplants spaced at $8 \mathrm{~cm}$ apart in the same ridge. This pattern was expressed as $100 \%$ faba bean $+55 \%$ onion.

13. Growing four rows of faba bean plants on one ridge ( 2 plants/hill spaced at $25 \mathrm{~cm}$ apart) on a ridge of $120 \mathrm{~cm}$ width. This pattern was expressed as sole faba bean (II).

14. Growing six rows of onion transplants spaced at $10 \mathrm{~cm}$ apart on ridge of $120 \mathrm{~cm}$ width. This pattern was expressed as sole onion (II).

15. Growing four rows of faba bean plants on one ridge ( 2 plants/hill spaced at $25 \mathrm{~cm}$ apart) on a ridge of $120 \mathrm{~cm}$ width, besides growing two rows of onion transplants spaced at $12 \mathrm{~cm}$ apart in the same ridge. This pattern was expressed as $100 \%$ faba bean $+27 \%$ onion.

16. Growing four rows of faba bean plants on one ridge ( 2 plants/hill spaced at $25 \mathrm{~cm}$ apart) on a ridge of $120 \mathrm{~cm}$ width, besides growing two rows of onion transplants spaced at $10 \mathrm{~cm}$ apart in the same ridge. This pattern was expressed as $100 \%$ faba bean $+33 \%$ onion.

17. Growing four rows of faba bean plants on one ridge ( 2 plants/hill spaced at $25 \mathrm{~cm}$ apart) on a ridge of $120 \mathrm{~cm}$ width, besides growing two rows of onion transplants spaced at $8 \mathrm{~cm}$ apart in the same ridge. This pattern was expressed as $100 \%$ faba bean $+41 \%$ onion.

18. Growing four rows of faba bean plants on one ridge ( 2 plants/hill spaced at $25 \mathrm{~cm}$ apart) on a ridge of $120 \mathrm{~cm}$ width, besides growing two rows of onion transplants spaced at $6 \mathrm{~cm}$ apart in the same ridge. This pattern was expressed as $100 \%$ faba bean $+55 \%$ onion.

\section{RECOMMENDED SOLE CULTURES OF BOTH CROPS WERE USED TO ESTIMATE THE COMPETITIVE RELATIONSHIPS.}

The recommended cultural practices for growing faba bean and onion crops were used.. The experimental soil texture was clay. Onion seedlings were sown on November $5^{\text {th }}$ and $7^{\text {th }}$ in 2013 and 2014 seasons, respectively, while, faba bean seeds were sown three weeks later. Onion seedlings (var. Giza 20) kindly provided by Onion Research Department, and faba bean seeds (var. Giza 843) kindly provided by Food Legumes Research Department, Field Crops Research Institute, ARC.

The experimental layout was conducted in split plot design with three replications by allocating the ridge widths in the main- plots and cropping systems in the sub-plots. Subplot area consisted of (12 ridges- $60 \mathrm{~cm}$ width or 8 ridges $-90 \mathrm{~cm}$ width and 6 ridges $-120 \mathrm{~cm}$ apart) and 3 meters long.

The studied traits: At harvest, ten plants were taken randomly from each sub-plot to estimate the following traits:

\section{a. ONION TRAITS:}

1. Plant height $(\mathrm{cm})$.

2. Number of leaves / plant. 
3. Bulb length (cm).

4. Bulb diameter $(\mathrm{cm})$.

5. Total weight of plant $(\mathrm{g})$

6. Bulb weight (g).

7. Bulbs yield (ton) / fad: it was recorded on the basis of experimental sub plot and expressed as ton per fad.

8. Faba bean seed yield (ardab) / fad: it was recorded on the basis of experimental sub-plot and expressed as ardab per fad.

a. COMPETITIVE RELATIONSHIPS AND YIELD ADVANTAGES:

1. Land equivalent ratio (LER): LER, defined as the ratio of area needed under solid cropping to one of intercropping at the same management level to produce an equivalent yield as proposed by Mead and Willey (1980).

2. Relative crowding coefficient (RCC): RCC, which estimates the relative dominance of one species over the other in the intercropping system as outlined by Banik et al.( 2006)

b. Aggressivity: Aggressivity which represents a simple measure of how much the relative yield increase in one crop is greater than the other in an intercropping system (Willey, 1979)

\section{c. Monetary Advantage Index (MAI)}

The prices of faba bean and onion were L.E. 740/ardab and L.E. 1500/ton (Bulletin of Statistical Cost Production and Net Return, 2015), MAI suggests that' the economic assessment should be in terms of the value of land saved; this could probably be most assessed on the basis of the rentable value of this land. MAI was calculated according to the formula, suggested by Willey (1979).

\section{STATISTICAL ANALYSIS:}

The data were subjected to proper statistical analysis of variance. The treatments means were compared by using the least significant differences (L.S.D.) test at $5 \%$ and $1 \%$ levels of probability, F test was also followed to differentiate among means of studied characters as recommended by Snedecor and Cochran (1973) and by SAS 2006 Statistical analysis program, SAS User's Guide: Statistics. SAS Institute Inc Editor, cary, NC.

\section{RESULTS AND DISCUSSION}

\section{A. BULBS YIELD AND ITS ATTRIBUTES}

\section{EFFECT OF RIDGE WIDTHS}


Data in Table (1) showed that' ridge widths had significant effects on bulbs length and diameter in both seasons, total weight of the plant in $1^{\text {st }}$ season, bulb weight in $2^{\text {nd }}$ season and bulbs yield (ton) per fad in both seasons; Meanwhile' plant height and number of leaves per plant in both seasons, as well as, total weight of the plant in $2^{\text {nd }}$ season and bulb weight in $1^{\text {st }}$ season were not significantly affected. Obviously, onion plants of ridges $120 \mathrm{~cm}$ had the highest bulb diameter in both seasons, total weight of the plant in $1^{\text {st }}$ season, bulb weight in $2^{\text {nd }}$ season and bulbs yield (ton) /fad in both seasons compared with the other ridge widths.

Different ridge width showed significant variations and the widest ridge width was superior to all the other ridge widths, where higher bulb diameter $\left(5.46 \mathrm{~cm}\right.$ in $1^{\text {st }}$ season and $5.01 \mathrm{~cm}$ in $2^{\text {nd }}$ season) was obtained, followed by $90 \mathrm{~cm}$ ridge width that had bulb diameter $4.32 \mathrm{~cm}$ in $1^{\text {st }}$ season and $4.23 \mathrm{~cm}$ in $2^{\text {nd }}$ season. On the other hand, the closest ridge width gave the lowest bulb diameter $4.11 \mathrm{~cm}$ in $1^{\text {st }}$ season and $4.02 \mathrm{~cm}$ in $2^{\text {nd }}$ season. These results could be due to that the widest ridge width furnished better above and under - ground conditions for onion plants to grow well compared to the other ridge widths. Accordingly, it is expected that' growth resources such as water and nutrients were more completely absorbed and converted to crop biomass during growth and development stages of onion. Significant maximum total weight of the plant (119.67 $\mathrm{g}$ in $1^{\text {st }}$ season) was obtained under the widest ridge width, followed by $90 \mathrm{~cm}$ ridge width with value of $113.00 \mathrm{~g}$ in $1^{\text {st }}$ season. Meanwhile' the closest ridge width gave minimum total weight of plant with value of $108.33 \mathrm{~g}$ in $1^{\text {st }}$ season. Significant maximum average bulb weight of the widest ridge width ( $81.00 \mathrm{~g}$ in $2^{\text {nd }}$ season) was obtained, followed by $90 \mathrm{~cm}$ ridge width with value of $77.80 \mathrm{~g}$ in $2^{\text {nd }}$ season weighed bulbs where there is no significant difference between both. On the other hand, the closest ridge width gave the lowest bulb weight (68.33 $\mathrm{g}$ in $2^{\text {nd }}$ season) compared with the others. The maximum bulb weight of the widest ridge width might be due

to more space available to bulb for expression

and less competition for nutrient and light. Its line with the finding of Balraj et al. (1998) who reported that' average bulb 
Table (1): Effect of ridge widths, cropping systems and their interactions on bulb yield and its attributes during the two seasons (2013/14 and 2014/15).

\begin{tabular}{|c|c|c|c|c|c|c|c|c|c|}
\hline \multirow{2}{*}{\multicolumn{2}{|c|}{$\begin{array}{l}\text { Traits } \\
\text { Treatments }\end{array}$}} & \multicolumn{2}{|c|}{$\begin{array}{c}\text { Plant height } \\
(\mathbf{c m})\end{array}$} & \multicolumn{2}{|c|}{ No. of leaves/plant } & \multicolumn{2}{|c|}{$\begin{array}{c}\text { Bulb length } \\
(\mathrm{cm})\end{array}$} & \multicolumn{2}{|c|}{$\begin{array}{l}\text { Bulb diameter } \\
(\mathbf{c m})\end{array}$} \\
\hline & & 2013/14 & $2014 / 15$ & 2013/14 & $2014 / 15$ & $2013 / 14$ & 2014/15 & 2013/14 & $2014 / 15$ \\
\hline \multicolumn{2}{|c|}{ Ridge widths $60 \mathrm{~cm}$} & 77.67 & 70.58 & 10.33 & 10.34 & 5.45 & 5.74 & 4.11 & 4.02 \\
\hline \multicolumn{2}{|l|}{$90 \mathrm{~cm}$} & 76.00 & 73.89 & 10.27 & 10.46 & 5.33 & 5.62 & 4.32 & 4.23 \\
\hline \multicolumn{2}{|c|}{$120 \mathrm{~cm}$} & 79.13 & 75.40 & 11.23 & 11.15 & 5.60 & 5.52 & 5.46 & 5.01 \\
\hline \multicolumn{2}{|l|}{ F - test } & N.S. & N.S. & N.S. & N.S. & $*$ & $*$ & $* *$ & $*$ \\
\hline \multirow[t]{2}{*}{ L.S.D } & $\mathbf{0 . 0 5}$ & --- & -- & --- & --- & 0.18 & 0.14 & --- & 0.64 \\
\hline & $\mathbf{0 . 0 1}$ & --- & --- & --- & --- & --- & --- & 0.95 & --- \\
\hline \multicolumn{2}{|c|}{ Cropping systemsSole onion } & 76.11 & 72.78 & 12.33 & 12.12 & 6.27 & 5.88 & 5.54 & 5.44 \\
\hline \multicolumn{2}{|c|}{$100 \%$ faba bean $+27 \%$ onion } & 78.33 & 70.44 & 10.67 & 10.78 & 5.59 & 5.68 & 4.76 & 4.41 \\
\hline \multicolumn{2}{|c|}{$100 \%$ faba bean $+33 \%$ onion } & 74.44 & 74.32 & 9.89 & 9.89 & 5.33 & 5.39 & 4.01 & 4.06 \\
\hline \multicolumn{2}{|c|}{$100 \%$ faba bean $+41 \%$ onion } & 81.11 & 74.50 & 10.06 & 10.12 & 4.76 & 5.62 & 4.58 & 3.90 \\
\hline \multicolumn{2}{|c|}{$100 \%$ faba bean $+55 \%$ onion } & 78.00 & 74.41 & 10.11 & 10.33 & 5.36 & 5.57 & 4.26 & 4.28 \\
\hline \multicolumn{2}{|c|}{ F - test } & N.S. & N.S. & $* *$ & $* *$ & $* *$ & $* *$ & $* *$ & $* *$ \\
\hline \multirow[t]{2}{*}{ L.S.D } & 0.05 & --- & -- & --- & --- & --- & --- & --- & --- \\
\hline & 0.01 & --- & -- & 1.21 & 1.06 & 0.68 & 0.24 & 0.58 & 0.56 \\
\hline \multicolumn{2}{|c|}{$\begin{array}{l}\text { Interactions } \\
60 \mathrm{~cm} \times \text { sole onion (Recommended) }\end{array}$} & 76.67 & 71.33 & 13.00 & 12.67 & 5.93 & 5.93 & 5.60 & 5.30 \\
\hline \multicolumn{2}{|c|}{$60 \mathrm{~cm} \times(100 \%$ faba bean $+27 \%$ onion $)$} & 81.67 & 70.67 & 9.67 & 10.67 & 6.07 & 5.83 & 3.93 & 3.67 \\
\hline
\end{tabular}




\begin{tabular}{|c|c|c|c|c|c|c|c|c|c|}
\hline \multicolumn{2}{|c|}{$60 \mathrm{~cm} \times(100 \%$ faba bean $+33 \%$ onion $)$} & 71.67 & 70.50 & 9.67 & 10.00 & 6.07 & 5.67 & 3.80 & 4.00 \\
\hline \multicolumn{2}{|c|}{$60 \mathrm{~cm} \times(100 \%$ faba bean $+41 \%$ onion $)$} & 73.33 & 68.50 & 9.33 & 9.03 & 4.33 & 5.67 & 3.60 & 3.77 \\
\hline \multicolumn{2}{|c|}{$60 \mathrm{~cm} \times(100 \%$ faba bean $+55 \%$ onion $)$} & 85.00 & 71.90 & 10.00 & 9.33 & 4.83 & 5.60 & 3.60 & 3.37 \\
\hline \multicolumn{2}{|c|}{$90 \mathrm{~cm} x$ sole onion $(\mathrm{I})$} & 70.00 & 72.00 & 11.00 & 12.30 & 6.33 & 5.90 & 4.83 & 5.50 \\
\hline \multicolumn{2}{|c|}{$90 \mathrm{~cm} \times(100 \%$ faba bean $+27 \%$ onion $)$} & 78.33 & 74.00 & 11.00 & 9.67 & 5.73 & 5.20 & 5.00 & 4.07 \\
\hline \multicolumn{2}{|c|}{$90 \mathrm{~cm} \times(100 \%$ faba bean $+33 \%$ onion $)$} & 73.33 & 74.47 & 9.33 & 9.33 & 4.43 & 5.30 & 3.43 & 3.33 \\
\hline \multicolumn{2}{|c|}{$90 \mathrm{~cm} \times(100 \%$ faba bean $+41 \%$ onion $)$} & 83.33 & 74.33 & 10.67 & 10.33 & 4.50 & 5.80 & 4.33 & 3.77 \\
\hline \multicolumn{2}{|c|}{$90 \mathrm{~cm} \times(100 \%$ faba bean $+55 \%$ onion $)$} & 75.00 & 74.67 & 9.33 & 10.67 & 5.67 & 5.90 & 4.00 & 4.47 \\
\hline \multicolumn{2}{|c|}{$120 \mathrm{~cm} x$ sole onion (II) } & 81.67 & 75.00 & 13.00 & 11.40 & 6.53 & 5.80 & 6.20 & 5.53 \\
\hline \multicolumn{2}{|c|}{$\begin{array}{l}120 \mathrm{~cm} \times(100 \% \text { faba bean }+27 \% \\
\text { onion) }\end{array}$} & 75.00 & 66.67 & 11.33 & 12.00 & 4.97 & 6.00 & 5.33 & 5.50 \\
\hline \multicolumn{2}{|c|}{$\begin{array}{l}120 \mathrm{~cm} \times(100 \% \text { faba bean }+33 \% \\
\text { onion })\end{array}$} & 78.33 & 78.00 & 10.67 & 10.33 & 5.50 & 5.20 & 4.80 & 4.83 \\
\hline \multicolumn{2}{|c|}{$120 \mathrm{~cm} \times(100 \%$ faba bean $+41 \%$ onion $)$} & 86.67 & 80.67 & 10.17 & 11.00 & 5.43 & 5.40 & 5.80 & 4.17 \\
\hline \multicolumn{2}{|c|}{$120 \mathrm{~cm} \times(100 \%$ faba bean $+55 \%$ onion $)$} & 74.00 & 76.67 & 11.00 & 11.00 & 5.57 & 5.20 & 5.17 & 5.00 \\
\hline \multicolumn{2}{|l|}{ F - test } & $* *$ & $*$ & $*$ & $*$ & $*$ & $* *$ & $*$ & $* *$ \\
\hline \multirow[t]{2}{*}{ L.S.D } & 0.05 & --- & 10.62 & 1.21 & 2.35 & 1.75 & --- & 1.30 & --- \\
\hline & 0.01 & 18.73 & -- & --- & --- & --- & 0.76 & -- & 1.67 \\
\hline
\end{tabular}

Table (1): Continued.

\begin{tabular}{|l|l|l|l|l|}
\hline Traits & $\begin{array}{l}\text { Total weight of plant } \\
(\mathrm{g})\end{array}$ & Bulb weight $(\mathrm{g})$ & $\begin{array}{l}\text { Bulbs } \\
(\text { ton/fad })\end{array}$ & $\begin{array}{c}\text { yield } \\
\text { Faba bean seed yield } \\
(\mathbf{a r d a b} / \mathbf{f a d})\end{array}$ \\
\hline
\end{tabular}


Journal of Environmental Studies and Researches (2017)

\begin{tabular}{|c|c|c|c|c|c|c|c|c|c|}
\hline \multicolumn{2}{|c|}{ Treatments } & $4^{2013 / 1}$ & 2014/15 & $4^{2013 / 1}$ & $5^{2014 / 1}$ & $4^{2013 / 1}$ & $5^{2014 / 1}$ & $4^{2013 / 1}$ & $5^{2014 / 1}$ \\
\hline \multicolumn{2}{|c|}{ Ridge widths $60 \mathrm{~cm}$} & 108.33 & 113.73 & 74.80 & 68.33 & 4.92 & 4.46 & 10.85 & 10.01 \\
\hline \multicolumn{2}{|l|}{$90 \mathrm{~cm}$} & 113.00 & 116.40 & 79.80 & 77.80 & 5.20 & 4.61 & 10.38 & 10.15 \\
\hline \multicolumn{2}{|c|}{$120 \mathrm{~cm}$} & 119.67 & 125.40 & 80.33 & 81.00 & 5.82 & 4.87 & 11.32 & 10.35 \\
\hline \multicolumn{2}{|c|}{ F - test } & $*$ & N.S. & N.S. & $* *$ & $* *$ & * & $*$ & $*$ \\
\hline \multirow[t]{2}{*}{ L.S.D } & 0.05 & 6.48 & --- & --- & --- & --- & $\mathbf{0 . 3 2}$ & 0.84 & 0.21 \\
\hline & 0.01 & --- & --- & -- & 8.94 & 0.61 & -- & -- & -- \\
\hline \multicolumn{2}{|c|}{ Cropping systems Sole onion } & 138.89 & 137.78 & 105.89 & 94.44 & 12.03 & 10.40 & 11.59 & 11.27 \\
\hline \multicolumn{2}{|c|}{$100 \%$ faba bean $+27 \%$ onion } & 115.56 & 114.89 & 74.44 & 75.56 & 2.78 & 2.31 & 10.99 & 10.49 \\
\hline \multicolumn{2}{|c|}{$100 \%$ faba bean $+33 \%$ onion } & 112.78 & 115.56 & 70.89 & 73.33 & 3.39 & 2.70 & 10.86 & 9.91 \\
\hline \multicolumn{2}{|c|}{$100 \%$ faba bean $+41 \%$ onion } & 94.44 & 114.33 & 67.78 & 65.00 & 3.67 & 3.45 & 10.60 & 9.48 \\
\hline \multicolumn{2}{|c|}{$100 \%$ faba bean $+55 \%$ onion } & 106.67 & 110.00 & 72.56 & 70.22 & 4.68 & 4.37 & 10.20 & 9.72 \\
\hline \multicolumn{2}{|c|}{ F - test } & $* *$ & $* *$ & $* *$ & $* *$ & $* *$ & $* *$ & $* *$ & $* *$ \\
\hline \multirow[t]{2}{*}{ L.S.D } & 0.05 & --- & -- & -- & -- & -- & -- & --- & -- \\
\hline & 0.01 & 12.99 & 11.31 & 6.92 & 8.25 & 0.56 & 0.68 & 0.84 & 0.59 \\
\hline \multicolumn{2}{|c|}{$\begin{array}{l}\text { Interactions } \\
60 \mathrm{~cm} \times \text { sole onion Recommended) }\end{array}$} & 138.33 & 140.00 & 103.33 & 95.00 & 12.15 & 10.20 & 11.83 & 11.00 \\
\hline \multicolumn{2}{|c|}{$60 \mathrm{~cm} \times(100 \%$ faba bean $+27 \%$ onion $)$} & 96.67 & 103.67 & 71.67 & 65.00 & 2.54 & 2.28 & 11.07 & 10.82 \\
\hline \multicolumn{2}{|c|}{$60 \mathrm{~cm} \times(100 \%$ faba bean $+33 \%$ onion $)$} & 120.00 & 119.33 & 77.00 & 71.67 & 3.20 & 2.62 & 10.73 & 9.63 \\
\hline \multicolumn{2}{|c|}{$60 \mathrm{~cm} \times(100 \%$ faba bean $+41 \%$ onion $)$} & 88.33 & 102.33 & 60.00 & 53.33 & 3.16 & 3.42 & 10.47 & 9.15 \\
\hline
\end{tabular}


Manal A.K.Z. Shehata et al

\begin{tabular}{|c|c|c|c|c|c|c|c|c|c|}
\hline \multicolumn{2}{|c|}{$60 \mathrm{~cm} \times(100 \%$ faba bean $+55 \%$ onion $)$} & 98.33 & 103.33 & 62.00 & 56.67 & 3.53 & 3.80 & 10.17 & 9.45 \\
\hline \multicolumn{2}{|c|}{$90 \mathrm{~cm} \times$ sole onion (I) } & 133.33 & 126.67 & 103.67 & 91.67 & 11.47 & 10.16 & 11.23 & 11.23 \\
\hline \multicolumn{2}{|c|}{$90 \mathrm{~cm} \times(100 \%$ faba bean $+27 \%$ onion $)$} & 113.33 & 110.00 & 78.33 & 75.00 & 2.8 & 2.26 & 10.20 & 10.08 \\
\hline \multicolumn{2}{|c|}{$90 \mathrm{~cm} \times(100 \%$ faba bean $+33 \%$ onion $)$} & 103.33 & 117.33 & 71.67 & 80.00 & 3.16 & 2.34 & 10.57 & 9.61 \\
\hline \multicolumn{2}{|c|}{$90 \mathrm{~cm} \times(100 \%$ faba bean $+41 \%$ onion $)$} & 98.33 & 114.00 & 71.33 & 63.33 & 3.68 & 3.68 & 10.34 & 10.08 \\
\hline \multicolumn{2}{|c|}{$90 \mathrm{~cm} \times(100 \%$ faba bean $+55 \%$ onion $)$} & 116.67 & 114.00 & 74.00 & 79.00 & 4.47 & 4.59 & 9.53 & 9.77 \\
\hline \multicolumn{2}{|c|}{$120 \mathrm{~cm} x$ sole onion (II) } & 145.00 & 146.67 & 110.67 & 96.67 & 12.47 & 10.83 & 11.70 & 11.57 \\
\hline \multicolumn{2}{|c|}{$120 \mathrm{~cm} \times(100 \%$ faba bean $+27 \%$ onion $)$} & 136.67 & 131.00 & 73.33 & 86.67 & 3.02 & 2.38 & 11.70 & 10.57 \\
\hline \multicolumn{2}{|c|}{$120 \mathrm{~cm} \times(100 \%$ faba bean $+33 \%$ onion $)$} & 115.00 & 110.00 & 64.00 & 68.33 & 3.80 & 3.14 & 11.30 & 10.48 \\
\hline \multicolumn{2}{|c|}{$120 \mathrm{~cm} \times(100 \%$ faba bean $+41 \%$ onion $)$} & 96.67 & 126.67 & 72.00 & 78.33 & 4.17 & 3.26 & 11.00 & 9.20 \\
\hline \multicolumn{2}{|c|}{$120 \mathrm{~cm} \times(100 \%$ faba bean $+55 \%$ onion $)$} & 105.00 & 112.67 & 81.67 & 75.00 & 5.65 & 4.73 & 10.90 & 9.93 \\
\hline \multicolumn{2}{|l|}{ F - test } & * & * & $* *$ & $* *$ & * & * & * & * \\
\hline \multirow[t]{2}{*}{ L.S.D } & 0.05 & 28.67 & 24.97 & --- & --- & 1.23 & 1.10 & 0.75 & 1.32 \\
\hline & 0.01 & --- & --- & 20.77 & 24.77 & --- & --- & --- & --- \\
\hline
\end{tabular}




\section{WEIGHT INCREASED WITH INCREA}

sing row spacing. Also, Kantona et al. (2003) observed that' mean bulb weight decreased as population density increased. Moreover, Khan $\boldsymbol{e t}$ al. (2003) demonstrated that the wider spacing gave maximum bulb weight. Finally, Saud et al. (2013) indicated that' maximum bulb weight was observed at $25 \mathrm{~cm}$ row spacing followed by $20 \mathrm{~cm}$ row spacing' while minimum average bulb weight was recorded at $15 \mathrm{~cm}$ row spacing.

The widest ridge width recorded the highest bulbs yield (ton) / fad in both seasons followed by $90 \mathrm{~cm}$ ridge width; Meanwhile' the lowest average bulbs yield/fad in both seasons was recorded by $60 \mathrm{~cm}$ ridge width. Generally' the closest ridge width could be resulted in less availability of soil nutrients, light and water etc; due to this the bulbs did not attain their respective size. Similar trend of results were observed by Balraj et al. (1998) who found that' increasing row spacing will result in an increase in onion yield. Conversely, Kantona et al. (2003) indicated that' total bulb yield increases significantly as population density increases.

\section{EFFECT OF CROPPING SYSTEMS}

Data in Table (1) showed that' cropping systems had significant effects on number of leaves per plant, bulbs length and diameter, plant total weight, bulb weight, bulbs yield/fad in both seasons, Meanwhile' plant height was not significantly affected. The results showed that' sole onion had the highest number of leaves per plant, bulbs length and diameter, total weight of the plant, bulb weight and blubs yield per fad in both seasons compared to those of intercropping patterns.

It is expected that' sole culture of onion could be decreased intra-specific competition for basic growth resources, especially solar radiation which increased number of leaves per plant and resulted in a positive effect on dry matter accumulation compared to those by intercropping systems. Obviously, sole culture of onion led to largely balance in plant-to-plant competition for climatic and edaphic environmental conditions that enhanced efficiency of photosynthetic process and converted more solar energy to chemical energy and more translocation of photosynthates metabolites to the sink. In this concern, Smittle (1993) showed that' onion bulbing is controlled by the hi-irradiance response of the phytochrome system which needs continuous irradiation and has a dependency on light intensity. He added that' bulbing increases more rapidly as the light intensity of inductive photoperiod's increases, delay in bulb initiation occurs when plants were shaded.

With respect to intercropping patterns, the maximum number of leaves per plant, bulbs length and diameter, total weight of the plant and bulb weight were obtained by intercropping pattern $100 \%$ faba bean $+27 \%$ onion. Conversely, this pattern had the lowest bulbs yield per fad in both seasons. Meanwhile the highest bulbs yield per fad in both seasons was recorded by intercropping pattern $100 \%$ faba bean $+55 \%$ onion. Obviously, the length and diameter of the bulb were decreased by increasing onion plant population density from 27 to $55 \%$ as a result of competition for light' which reflected on bulb weight (Kapczyńska, 2013) but the highest plant density of onion contributed largely in increasing bulbs yield per fad.

\section{EFFECT OF THE INTERACTION BETWEEN RIDGE WIDTHS AND CROPPING SYSTEMS}


Data in Table (1) showed that' the interaction between ridge widths and cropping systems had significant effects on plant height, number of leaves per plant, bulbs length and diameter, total weight of the plant, bulb weight and bulbs yield per fad in both seasons. The highest tall of plants was detected by all interactions except the interactions of $60 \mathrm{~cm}$ ridge width $\mathrm{x} 100 \%$ faba bean $+33 \%$ onion and $90 \mathrm{~cm} \times$ sole onion in the first season and $60 \mathrm{~cm} \times 100 \%$ faba bean $+41 \%$ onion and $120 \mathrm{~cm} \times 100 \%$ faba bean $+27 \%$ onion in the second season where the values of non excepted interactions had no significant differences. The maximum no.of leaves per plant was observed by the interactions of $60 \mathrm{~cm}$ ridge width $\times$ sole onion and $120 \mathrm{~cm}$ ridge width $\times$ sole onion in the first season and $60 \mathrm{~cm}$ ridge width $\times$ sole onion in the second season. The maximum length of bulbs was detected by the interactions of $120 \mathrm{~cm}$ ridge width $\times$ sole onion (II) in the first season and $60 \mathrm{~cm}$ ridge width $\times$ sole onion in the second season. The maximum diameter of bulbs was observed by the interactions of $120 \mathrm{~cm}$ ridge width $\times$ sole onion (II) in both seasons. Moreover, the total weight of plant, bulb weight, bulb yield (ton) / faddan were detected by the interactions; $60 \mathrm{~cm}$ ridge width $\times$ sole onion (recommended), 90 $\mathrm{cm}$ ridge width $\times$ sole onion (I) and 120 ridge width $\times$ sole onion (II) in both season, where there is no significant deference between these interactions with respect to each of the trait in view. These data showed that' each of these two factors act dependently on plant height, number of leaves per plant, bulbs length and diameter, total weight of the plant, bulb weight and bulbs yield per fad meaning that' ridge widths responded differently to cropping systems for these studied traits of onion.

\section{RELATIVE YIELDS AND LAND EQUIVALENT RATIO (LER)}

The values of LER were estimated by using data of sole cultures of both crops. Intercropping onion with faba bean increased LER as compared to sole cultures of both crops in both seasons.

\section{EFFECT OF RIDGE WIDTHS}

Data shown in Table (2) showed that' ridge widths had significant effects on relative yields of onion and faba bean and LER in both seasons' except relative yield of faba bean in $2^{\text {nd }}$ season which was not significantly affected.

The results showed that' the widest ridge width $120 \mathrm{~cm}$ had the highest relative yields of onion and faba bean and LER. Meanwhile' closest ridge width $60 \mathrm{~cm}$ produced the lowest relative yields of onion and faba bean and LER compared to the other ridge width.

These results could be due to that the widest ridge width had the highest number of plants per unit area which reflected positively on final yield per unit area and relative yields of both species.

\section{EFFECT OF CROPPING SYSTEMS}

Data appeared in Table (2) showed that' cropping systems had significant effects on relative yields of faba bean and onion and LER in both seasons. With respect to onion crop, increasing plant density of onion from 27 to $55 \%$ of sole culture significantly increased relative yield of onion from 0.229 to 0.374 in $1^{\text {st }}$ season and from 0.259 to 0.429 in $2^{\text {nd }}$ season under intercropping conditions. While' with respect to relative yield of faba bean crop, increasing plant density of onion from 27 to $55 \%$ of sole culture significantly decreased relative yield of faba bean from 0.929 to 0.862 in $1^{\text {st }}$ season and from 0.954 to 0.883 in $2^{\text {nd }}$ season (Table 2 ) under intercropping conditions.

These results could be due to that the lowest plant density of onion could be decreased inter - specific competition between onion and faba bean for basic growth resources which reflected positively on the economic yield of faba bean under intercropping conditions. These results 
could be due to intercropping pattern $100 \%$ faba bean $+55 \%$ onion had the highest plant density of onion that contributed largely in increasing bulbs yield per fad and in turn relative yield of onion. Land equivalent ratio (LER) was significantly increased with increasing plant density of onion from 27 to $55 \%$ under intercropping culture in both seasons (Table 2). The advantage of the highest LER by intercropping pattern $100 \%$ faba bean $+55 \%$ onion over the others could be due to that the highest plant density of onion contributed largely in increasing yield of the intercrops per fad. These results are in the same line with those obtained by El-Hawary $\boldsymbol{e t}$ al. (1991), El Kalla et al. (1999) and Abou-Keriasha et al. (2013).

\section{EFFECT OF THE INTERACTION BETWEEN RIDGE WIDTHS AND CROPPING SYSTEMS}

Data in Table (2) showed that' the interaction between ridge widths and cropping systems had significant effects on relative yields of onion and faba bean and LER in both seasons. The results indicate that' the maximum relative yield of onion $\left(0.465 \mathrm{~cm}\right.$ in $1^{\text {st }}$ season and $0.464 \mathrm{~cm}$ in $2^{\text {nd }}$ season) and LER (1.38 in $1^{\text {st }}$ season and 1.36 in $2^{\text {nd }}$ season) were obtained by intercropping pattern of $100 \%$ faba bean $+55 \%$ onion on ridge width of $120 \mathrm{~cm}$. Obviously, doubling ridge width from $60 \mathrm{~cm}$ to $120 \mathrm{~cm}$ integrated with the highest plant density of onion to decrease inter and intra - specific competition between onion and faba bean for basic growth resources' which reflected positively on the economic yield of both species under intercropping culture. These data showed that' each of these two factors act dependently with respect to relative yield of faba bean, where there is no obvious trend in this respect. 
Table (2): Relative yields(RY) and land equivalent ratio ( LER ) as affected by ridge width, cropping systems and their interaction during $2013 / 14$ and $2014 / 15$ seasons.

\begin{tabular}{|c|c|c|c|c|c|c|c|}
\hline \multirow{2}{*}{\multicolumn{2}{|c|}{$7^{\text {Traits }}$}} & \multicolumn{2}{|c|}{$\begin{array}{l}\text { Relative yield of onion } \\
\text { RYonion }\end{array}$} & \multicolumn{2}{|c|}{$\begin{array}{l}\text { Relative yield of faba bean } \\
\text { RY faba bean }\end{array}$} & \multicolumn{2}{|c|}{$\begin{array}{l}\text { Land equivalent ratio } \\
\text { LER }\end{array}$} \\
\hline & & $2013 / 14$ & $2014 / 15$ & $2013 / 14$ & $2014 / 15$ & $2013 / 14$ & $2014 / 15$ \\
\hline \multicolumn{2}{|c|}{ Ridge widths $60 \mathrm{~cm}$} & 0.256 & 0.297 & 0.897 & 0.888 & 1.15 & 1.18 \\
\hline \multicolumn{2}{|l|}{$90 \mathrm{~cm}$} & 0.290 & 0.325 & 0.859 & 0.899 & 1.14 & 1.21 \\
\hline \multicolumn{2}{|c|}{$120 \mathrm{~cm}$} & 0.349 & 0.390 & 0.950 & 0.913 & 1.29 & 1.24 \\
\hline \multicolumn{2}{|c|}{ F - test } & * & $*$ & $*$ & N.S. & $*$ & $*$ \\
\hline \multirow[t]{2}{*}{ L.S.D } & 0.05 & 0.038 & 0.064 & 0.031 & --- & 0.016 & 0.060 \\
\hline & $\mathbf{0 . 0 1}$ & -- & --- & --- & --- & --- & --- \\
\hline \multicolumn{8}{|c|}{ Intercropping patterns } \\
\hline \multicolumn{2}{|c|}{$100 \%$ faba bean $+27 \%$ onion } & 0.229 & 0.259 & 0.929 & 0.954 & 1.15 & 1.18 \\
\hline \multicolumn{2}{|c|}{$100 \%$ faba bean $+33 \%$ onion } & 0.279 & 0.291 & 0.919 & 0.901 & 1.19 & 1.16 \\
\hline \multicolumn{2}{|c|}{$100 \%$ faba bean $+41 \%$ onion } & 0.302 & 0.371 & 0.896 & 0.862 & 1.19 & 1.20 \\
\hline \multicolumn{2}{|c|}{$100 \%$ faba bean $+55 \%$ onion } & 0.374 & 0.429 & 0.862 & 0.883 & 1.23 & 1.31 \\
\hline \multicolumn{2}{|c|}{ F - test } & * & $*$ & $*$ & $*$ & $*$ & $*$ \\
\hline \multirow[t]{2}{*}{ L.S.D } & 0.05 & 0.034 & 0.035 & 0.018 & 0.043 & 0.070 & 0.070 \\
\hline & 0.01 & -- & --- & --- & -- & --- & --- \\
\hline \multicolumn{2}{|c|}{$\begin{array}{l}\text { Interactions } \\
60 \mathrm{~cm} \times(100 \% \text { faba bean }+27 \% \text { onion })\end{array}$} & 0.209 & 0.224 & 0.936 & 0.984 & 1.14 & 1.20 \\
\hline \multicolumn{2}{|c|}{$60 \mathrm{~cm} \times(100 \%$ faba bean $+33 \%$ onion $)$} & 0.263 & 0.257 & 0.907 & 0.875 & 1.17 & 1.13 \\
\hline
\end{tabular}


Journal of Environmental Studies and Researches (2017)

\begin{tabular}{|c|c|c|c|c|c|c|c|}
\hline \multicolumn{2}{|c|}{$60 \mathrm{~cm} \times(100 \%$ faba bean $+41 \%$ onion $)$} & 0.260 & 0.335 & 0.885 & 0.832 & 1.14 & 1.16 \\
\hline \multicolumn{2}{|c|}{$60 \mathrm{~cm} \times(100 \%$ faba bean $+55 \%$ onion $)$} & 0.291 & 0.373 & 0.860 & 0.859 & 1.15 & 1.23 \\
\hline \multicolumn{2}{|c|}{$90 \mathrm{~cm} \times(100 \%$ faba bean $+27 \%$ onion $)$} & 0.230 & 0.222 & 0.862 & 0.916 & 1.09 & 1.13 \\
\hline \multicolumn{2}{|c|}{$90 \mathrm{~cm} \times(100 \%$ faba bean $+33 \%$ onion $)$} & 0.260 & 0.229 & 0.893 & 0.874 & 1.15 & 1.10 \\
\hline \multicolumn{2}{|c|}{$90 \mathrm{~cm} \times(100 \%$ faba bean $+41 \%$ onion $)$} & 0.303 & 0.361 & 0.874 & 0.916 & 1.17 & 1.27 \\
\hline \multicolumn{2}{|c|}{$90 \mathrm{~cm} \times(100 \%$ faba bean $+55 \%$ onion $)$} & 0.368 & 0.450 & 0.806 & 0.888 & 1.17 & 1.33 \\
\hline \multicolumn{2}{|c|}{$120 \mathrm{~cm} \times(100 \%$ faba bean $+27 \%$ onion $)$} & 0.249 & 0.233 & 0.989 & 0.961 & 1.23 & 1.19 \\
\hline \multicolumn{2}{|c|}{$120 \mathrm{~cm} \times(100 \%$ faba bean $+33 \%$ onion $)$} & 0.313 & 0.308 & 0.955 & 0.953 & 1.26 & 1.26 \\
\hline \multicolumn{2}{|c|}{$120 \mathrm{~cm} \times(100 \%$ faba bean $+41 \%$ onion $)$} & 0.343 & 0.320 & 0.930 & 0.836 & 1.27 & 1.15 \\
\hline \multicolumn{2}{|c|}{$120 \mathrm{~cm} \times(100 \%$ faba bean $+55 \%$ onion $)$} & 0.465 & 0.464 & 0.921 & 0.903 & 1.38 & 1.36 \\
\hline \multicolumn{2}{|c|}{ F - test } & * & * & $*$ & * & * & $*$ \\
\hline \multirow[t]{2}{*}{ L.S.D } & 0.05 & $\mathbf{0 . 0 1 5}$ & 0.063 & 0.089 & $\mathbf{0 . 0 5 7}$ & 0.123 & 0.121 \\
\hline & $\mathbf{0 . 0 1}$ & --- & --- & -- & --- & --- & --- \\
\hline
\end{tabular}




\section{E. RELATIVE CROWDING COEFFICIENT (RCC)}

\section{EFFECT OF RIDGE WIDTHS}

Data in Table (3) showed that' ridge widths had significant effects on RCC in both seasons' where the widest ridge width of $120 \mathrm{~cm}$ had the highest RCC, meanwhile' the ridge width of $90 \mathrm{~cm}$ produced the lowest RCC compared to the other ridge widths.However, there is no significant difference between ridge width of $120 \mathrm{~cm}$ and $60 \mathrm{~cm}$ in the second season in this concern.

These results could be due to that the widest ridge width had the highest number of plants per unit area' which reflected positively on final yield per unit area.

\section{EFFECT OF CROPPING SYSTEMS}

Data in Table (3) showed that' cropping systems had significant effects on RCC in both seasons. Intercropping pattern $100 \%$ faba bean $+27 \%$ onion had the highest RCC compared to the other intercropping patterns. These results could be due to that the lowest plant density of onion could be decreased inter or intra - specific competition between plants of the two species or plants of the same species, respectively, for basic growth resources which reflected positively on the economic yield of faba bean under intercropping conditions.

\section{EFFECT OF THE INTERACTION BETWEEN RIDGE WIDTHS AND CROPPING SYSTEMS}

Data in Table (3) showed that' the interaction between ridge widths and cropping systems had significant effects on RCC in both seasons. The results showed that' the maximum RCC ( 29.77 in $1^{\text {st }}$ season) was obtained by intercropping pattern of $100 \%$ faba bean $+27 \%$ onion of ridge width $120 \mathrm{~cm}$. While, intercropping patterns of $60 \mathrm{~cm} \times(100 \%$ faba bean $+27 \%$ onion), $120 \mathrm{~cm} \times(100 \%$ faba bean $+27 \%$ onion $), 120 \mathrm{~cm}(100 \%$ faba bean $+33 \%$ onion $)$ and $120 \mathrm{~cm}$ $\mathrm{x}(100 \%$ faba been $+55 \%$ onion $)$ had the highest values of RCC in the second season, where there is no significant difference between these intercropping patterns. 

Table (3): Relative crowding coefficient (RCC) as affected by ridge width, cropping systems and their interaction during 2013/14 and 2014/15 seasons.

\begin{tabular}{|c|c|c|c|c|c|c|c|}
\hline \multirow{2}{*}{\multicolumn{2}{|c|}{ Treatments }} & \multicolumn{2}{|c|}{$K_{\text {faba bean }}$} & \multicolumn{2}{|l|}{$K_{\text {onion }}$} & \multicolumn{2}{|c|}{$\begin{array}{l}\text { Relative crowding coefficient } \\
\text { RCC }\end{array}$} \\
\hline & & 2013/14 & 2014/15 & 2013/14 & 2014/15 & 2013/14 & 2014/15 \\
\hline \multirow{2}{*}{\multicolumn{2}{|c|}{ Ridge widths }} & & & & & & \\
\hline & & 3.42 & 5.98 & 0.92 & 1.11 & 3.14 & 6.46 \\
\hline \multicolumn{2}{|l|}{$90 \mathrm{~cm}$} & 2.40 & 3.53 & 1.07 & 1.21 & 2.56 & 4.46 \\
\hline \multicolumn{2}{|c|}{$120 \mathrm{~cm}$} & 10.80 & 5.12 & 1.36 & 1.30 & 14.15 & 6.72 \\
\hline \multicolumn{2}{|c|}{ F - test } & $*$ & * & * & * & $*$ & $*$ \\
\hline \multirow[t]{2}{*}{ L.S.D } & 0.05 & 4.23 & 1.20 & 0.31 & 0.05 & 6.74 & 1.85 \\
\hline & 0.01 & -- & --- & --- & -- & --- & --- \\
\hline \multicolumn{2}{|c|}{$\begin{array}{l}\text { Intercropping patterns } \\
100 \% \text { faba bean }+27 \% \text { onion }\end{array}$} & 9.97 & 8.61 & 1.10 & 1.08 & 11.83 & 9.30 \\
\hline \multicolumn{2}{|c|}{$100 \%$ faba bean $+33 \%$ onion } & 4.34 & 3.75 & 1.18 & 1.10 & 5.38 & 4.48 \\
\hline \multicolumn{2}{|c|}{$100 \%$ faba bean $+41 \%$ onion } & 3.81 & 2.87 & 1.06 & 1.25 & 4.22 & 3.69 \\
\hline \multicolumn{2}{|c|}{$100 \%$ faba bean $+55 \%$ onion } & 4.03 & 4.28 & 1.13 & 1.38 & 5.04 & 6.05 \\
\hline \multicolumn{2}{|c|}{ F - test } & $*$ & $*$ & * & $*$ & $*$ & $*$ \\
\hline \multirow[t]{2}{*}{ L.S.D } & 0.05 & 3.67 & 3.95 & 0.05 & 0.18 & 4.58 & 4.36 \\
\hline & 0.01 & --- & --- & --- & --- & --- & --- \\
\hline \multicolumn{2}{|c|}{$\begin{array}{l}\text { Interactions } \\
60 \mathrm{~cm} \times(100 \% \text { faba bean }+27 \% \text { onion })\end{array}$} & 3.93 & 16.23 & 0.98 & 1.07 & 3.85 & 17.30 \\
\hline
\end{tabular}




\begin{tabular}{|c|c|c|c|c|c|c|c|}
\hline \multicolumn{2}{|c|}{$60 \mathrm{~cm} \times(100 \%$ faba bean $+33 \%$ onion $)$} & 3.22 & 2.32 & 1.08 & 1.05 & 3.49 & 2.43 \\
\hline \multicolumn{2}{|c|}{$60 \mathrm{~cm} \times(100 \%$ faba bean $+41 \%$ onion $)$} & 3.16 & 2.03 & 0.86 & 1.23 & 2.71 & 2.49 \\
\hline \multicolumn{2}{|c|}{$60 \mathrm{~cm} \times(100 \%$ faba bean $+55 \%$ onion $)$} & 3.37 & 3.35 & 0.74 & 1.08 & 2.51 & 3.62 \\
\hline \multicolumn{2}{|c|}{$90 \mathrm{~cm} \times(100 \%$ faba bean $+27 \%$ onion $)$} & 1.69 & 2.96 & 1.11 & 1.05 & 1.87 & 3.12 \\
\hline \multicolumn{2}{|c|}{$90 \mathrm{~cm} \times(100 \%$ faba bean $+33 \%$ onion $)$} & 2.77 & 2.28 & 1.07 & 0.90 & 2.95 & 2.06 \\
\hline \multicolumn{2}{|c|}{$90 \mathrm{~cm} \times(100 \%$ faba bean $+41 \%$ onion $)$} & 2.85 & 4.49 & 1.06 & 1.38 & 3.02 & 6.18 \\
\hline \multicolumn{2}{|c|}{$90 \mathrm{~cm} \times(100 \%$ faba bean $+55 \%$ onion $)$} & 2.28 & 4.37 & 1.06 & 1.49 & 2.41 & 6.50 \\
\hline \multicolumn{2}{|c|}{$120 \mathrm{~cm} \times(100 \%$ faba bean $+27 \%$ onion $)$} & 24.30 & 6.64 & 1.23 & 1.13 & 29.77 & 7.48 \\
\hline \multicolumn{2}{|c|}{$120 \mathrm{~cm} \times(100 \%$ faba bean $+33 \%$ onion $)$} & 7.04 & 6.65 & 1.38 & 1.35 & 9.70 & 8.96 \\
\hline \multicolumn{2}{|c|}{$120 \mathrm{~cm} \times(100 \%$ faba bean $+41 \%$ onion $)$} & 5.43 & 2.10 & 1.27 & 1.15 & 6.93 & 2.40 \\
\hline \multicolumn{2}{|c|}{$120 \mathrm{~cm} \times(100 \%$ faba bean $+55 \%$ onion $)$} & 6.45 & 5.10 & 1.58 & 1.57 & 10.19 & 8.02 \\
\hline \multicolumn{2}{|c|}{ F - test } & * & $*$ & * & * & * & * \\
\hline \multirow[t]{2}{*}{ L.S.D } & 0.05 & 16.20 & 10.30 & $\mathbf{0 . 1 8}$ & 0.09 & 19.52 & 11.60 \\
\hline & 0.01 & --- & --- & --- & --- & --- & --- \\
\hline
\end{tabular}



Obviously, doubling ridge width from 60 to 120 integrated with the lowest plant density of onion to decrease inter or intra - specific competition between plants of the two species or plants of the same species, respectively, for basic growth resources which reflected positively on the economic yield of both species under intercropping conditions. These data revealed that' there was effect of ridge widths $\mathrm{x}$ intercropping patterns on $\mathrm{RCC}$

\section{F. AGGRESSIVITY}

Aggressivity determines the difference in competitive ability of the component crops in intercropping association. The positive sign indicates the dominant component and the negative sign indicates the dominated component. Higher numerical values of aggressiveness denote greater difference in competitive ability, as well as, bigger difference between actual and expected yield in both crops. The results indicate that' the value of aggressivity of faba bean was positive for all treatments, while, the values of aggressivity were negative for all intercropped onion with faba bean in both seasons (Table 4). These data showed that' faba bean and onion plants are dominant and dominated components, respectively.

\section{EFFECT OF RIDGE WIDTHS}

Data shown in Table (4) revealed that' ridge widths had significant effects on aggressivity in both seasons' where the widest ridge width $120 \mathrm{~cm}$ had the lowest values of aggressivity, meanwhile' the ridge width $60 \mathrm{~cm}$ produced the highest values of aggressivity compared to the others ridge widths.

Significantly maximum aggressivity ( 0.28 in $1^{\text {st }}$ season and 0.16 in $2^{\text {nd }}$ season $)$ were obtained by growing intercrops at ridges of $60 \mathrm{~cm}$ width, while the ridge width of $120 \mathrm{~cm}$ gave minimum aggressivity (0.09 in $1^{\text {st }}$ season and 0.08 in $2^{\text {nd }}$ season).

\section{EFFECT OF INTERCROPPING SYSTEMS}

Data in Table (4) showed that' intercropping systems had no significant effects on aggressivity in both seasons. 

Table (4): Aggressivity as affected by ridge width, cropping systems and their interaction during 2013/14 and 2014/15 seasons.

\begin{tabular}{|c|c|c|c|c|c|}
\hline \multirow{2}{*}{\multicolumn{2}{|c|}{$\begin{array}{ll} & \text { Traits } \\
\text { Treatments } & \\
\end{array}$}} & \multicolumn{2}{|c|}{ Agg+ faba bean } & \multicolumn{2}{|c|}{ Agg- onion } \\
\hline & & 2013/14 & $2014 / 15$ & 2013/14 & $2014 / 15$ \\
\hline \multicolumn{2}{|c|}{ Ridge widths } & & & & \\
\hline \multicolumn{2}{|l|}{$60 \mathrm{~cm}$} & +0.28 & +0.16 & -0.28 & -0.16 \\
\hline \multicolumn{2}{|l|}{$90 \mathrm{~cm}$} & +0.14 & +0.13 & -0.14 & -0.13 \\
\hline \multicolumn{2}{|l|}{$120 \mathrm{~cm}$} & +0.09 & +0.08 & -0.09 & -0.08 \\
\hline \multicolumn{2}{|l|}{ F - test } & * & * & * & * \\
\hline \multirow[t]{2}{*}{ L.S.D } & 0.05 & 0.025 & 0.020 & 0.025 & 0.020 \\
\hline & $\mathbf{0 . 0 1}$ & --- & -- & --- & -- \\
\hline \multicolumn{2}{|c|}{ Intercropping patterns } & & & & \\
\hline \multicolumn{2}{|c|}{$100 \%$ faba bean $+27 \%$ onion } & +0.10 & +0.15 & -0.10 & -0.15 \\
\hline \multicolumn{2}{|c|}{$100 \%$ faba bean $+33 \%$ onion } & +0.10 & +0.13 & -0.10 & -0.13 \\
\hline \multicolumn{2}{|c|}{$100 \%$ faba bean $+41 \%$ onion } & +0.23 & +0.05 & -0.23 & -0.05 \\
\hline \multicolumn{2}{|c|}{$100 \%$ faba bean $+55 \%$ onion } & +0.28 & +0.16 & -0.28 & -0.16 \\
\hline \multicolumn{2}{|l|}{ F - test } & N.S. & N.S. & N.S. & N.S. \\
\hline \multirow[t]{2}{*}{ L.S.D } & 0.05 & --- & -- & -- & --- \\
\hline & 0.01 & --- & -- & -- & --- \\
\hline \multicolumn{2}{|c|}{ Interactions } & & & & \\
\hline \multicolumn{2}{|c|}{$60 \mathrm{~cm} \times(100 \%$ faba bean $+27 \%$ onion $)$} & +0.21 & +0.20 & -0.21 & -0.20 \\
\hline \multicolumn{2}{|c|}{$60 \mathrm{~cm} \times(100 \%$ faba bean $+33 \%$ onion $)$} & +0.14 & +0.13 & -0.14 & -0.13 \\
\hline \multicolumn{2}{|c|}{$60 \mathrm{~cm} \times(100 \%$ faba bean $+41 \%$ onion $)$} & +0.35 & +0.02 & -0.35 & -0.02 \\
\hline
\end{tabular}


Manal A.K.Z. Shehata et al.

\begin{tabular}{|c|c|c|c|c|c|}
\hline \multicolumn{2}{|c|}{$60 \mathrm{~cm} \times(100 \%$ faba bean $+55 \%$ onion $)$} & +0.51 & +0.28 & -0.51 & -0.28 \\
\hline \multicolumn{2}{|c|}{$90 \mathrm{~cm} \times(100 \%$ faba bean $+27 \%$ onion $)$} & +0.01 & +0.12 & -0.01 & -0.12 \\
\hline \multicolumn{2}{|c|}{$90 \mathrm{~cm} \times(100 \%$ faba bean $+33 \%$ onion $)$} & +0.14 & +0.24 & -0.14 & -0.24 \\
\hline \multicolumn{2}{|c|}{$90 \mathrm{~cm} \times(100 \%$ faba bean $+41 \%$ onion $)$} & +0.19 & +0.05 & -0.19 & -0.05 \\
\hline \multicolumn{2}{|c|}{$90 \mathrm{~cm} \times(100 \%$ faba bean $+55 \%$ onion $)$} & +0.21 & +0.11 & -0.21 & -0.11 \\
\hline \multicolumn{2}{|c|}{$120 \mathrm{~cm} \times(100 \%$ faba bean $+27 \%$ onion $)$} & +0.09 & +0.12 & -0.09 & -0.12 \\
\hline \multicolumn{2}{|c|}{$120 \mathrm{~cm} \times(100 \%$ faba bean $+33 \%$ onion $)$} & +0.01 & +0.03 & -0.01 & -0.03 \\
\hline \multicolumn{2}{|c|}{$120 \mathrm{~cm} \times(100 \%$ faba bean $+41 \%$ onion $)$} & +0.13 & +0.08 & -0.13 & -0.08 \\
\hline \multicolumn{2}{|c|}{$120 \mathrm{~cm} \times(100 \%$ faba bean $+55 \%$ onion $)$} & +0.12 & +0.09 & -0.12 & -0.09 \\
\hline \multicolumn{2}{|c|}{ F - test } & * & * & $*$ & * \\
\hline \multirow[t]{2}{*}{ L.S.D } & 0.05 & 0.142 & 0.120 & 0.142 & 0.120 \\
\hline & 0.01 & --- & --- & --- & --- \\
\hline
\end{tabular}





\section{EFFECT OF THE INTERACTION BETWEEN RIDGE WIDTHS AND CROPPING SYSTEMS}

Data shown in Table (4) pointed out that' the interaction between ridge widths and cropping systems had significant effects on aggressivity in both seasons. The maximum aggressivity ( 0.51 in $1^{\text {st }}$ season and 0.28 in $2^{\text {nd }}$ season) was obtained by intercropping pattern of $100 \%$ faba bean $+55 \%$ onion of ridge width $60 \mathrm{~cm}$. Obviously, ridge width of $60 \mathrm{~cm}$ integrated with the highest plant density of onion to increase inter - or intra specific competition between plants of the two species or plants of the same species, respectively, for basic growth resources. In other words, increasing plant density of onion led to increased competitive pressure between plants of the two species or plants of the same species, respectively, for basic growth resources and this effect was decreased by increasing ridge width from 60 to $120 \mathrm{~cm}$ under intercropping conditions. These data showed that' each of these two factors act dependently on aggressivity.

\section{G. INTERCROPPING ECONOMIC ADVANTAGE}

The economic performance of the intercropping was evaluated to determine if onion and faba bean combined yields are high enough for the farmers to adopt this system. The data listed in Tabe (5) revealed that' the averages of monetary advantage index (MAI) values of intercropping $100 \%$ faba bean $+55 \%$ onion of ridge width $120 \mathrm{~cm}$ achieved the highest MAI (L.E. 4554.76 in $1^{\text {st }}$ season and L.E. 4013.20 in $2^{\text {nd }}$ season) compared to the others. However, the lowest MAI was achieved by ridge width $90 \mathrm{~cm} \times$ intercropping pattern $100 \%$ faba bean + $27 \%$ onion in $1^{\text {st }}$ season and by ridge width $90 \mathrm{~cm} \times$ intercropping pattern $100 \%$ faba bean + $33 \%$ onion in $2^{\text {nd }}$ season. Differences between the highest and the lowest values of MAI were L.E. 3584.75 in $1^{\text {st }}$ season and L.E. 3047.62 in $2^{\text {nd }}$ season. Obviously, intercropping $100 \%$ faba bean $+55 \%$ onion of ridge width $120 \mathrm{~cm}$ resulted in high profitability and could be recommended. These results are in parallel with those observed by Abou-Keriasha et al. (2013). 
Table (7): Economic return as affected by ridge width, cropping systems and their interaction during 2013/14 and 2014/15 seasons

\begin{tabular}{|c|c|c|c|c|c|c|c|c|}
\hline \multirow{3}{*}{ Treatments } & \multicolumn{8}{|c|}{ Economic return/fad (L.E.) } \\
\hline & \multicolumn{2}{|c|}{ Onion } & \multicolumn{2}{|c|}{ Faba bean } & \multicolumn{2}{|c|}{ Total } & \multicolumn{2}{|c|}{$\begin{array}{l}\text { Monetary advantag } \\
\text { index (MAI) }\end{array}$} \\
\hline & 2013/14 & $2014 / 15$ & 2013/14 & $2014 / 15$ & 2013/14 & $2014 / 15$ & 2013/14 & $2014 / 15$ \\
\hline $60 \mathrm{~cm} \times(100 \%$ faba bean $+27 \%$ onion $)$ & 3810 & 3420 & 8191.8 & 8006.8 & 12001.8 & 11426.8 & 1473.90 & 1904.46 \\
\hline $60 \mathrm{~cm} \times(100 \%$ faba bean $+33 \%$ onion $)$ & 4800 & 3930 & 7940.2 & 7126.2 & 12740.2 & 11056.2 & 1851.14 & 1271.95 \\
\hline $60 \mathrm{~cm} \times(100 \%$ faba bean $+41 \%$ onion $)$ & 4740 & 5130 & 7747.8 & 6771.0 & 12487.8 & 11901.0 & 1533.58 & 1641.51 \\
\hline $60 \mathrm{~cm} \times(100 \%$ faba bean $+55 \%$ onion $)$ & 5295 & 5700 & 7525.8 & 6993.0 & 12820.8 & 12693.0 & 1672.27 & 2373.48 \\
\hline $90 \mathrm{~cm} \times(100 \%$ faba bean $+27 \%$ onion $)$ & 4200 & 3390 & 7548.0 & 7459.2 & 11748.0 & 10849.2 & 970.01 & 1248.13 \\
\hline $90 \mathrm{~cm} \times(100 \%$ faba bean $+33 \%$ onion $)$ & 4740 & 3510 & 7821.8 & 7111.4 & 12561.8 & 10621.4 & 1638.49 & 965.58 \\
\hline $90 \mathrm{~cm} \times(100 \%$ faba bean $+41 \%$ onion $)$ & 5520 & 5520 & 7651.6 & 7459.2 & 13171.6 & 12979.2 & 1913.82 & 2759. \\
\hline $90 \mathrm{~cm} \times(100 \%$ faba bean $+55 \%$ onion $)$ & 6705 & 6885 & 7052.2 & 7229.8 & 13757.2 & 14114.8 & 1998.90 & 3502.16 \\
\hline $120 \mathrm{~cm} \times(100 \%$ faba bean $+27 \%$ onion $)$ & 4530 & 3570 & 8658.0 & 7821.8 & 13188.0 & 11391.8 & 2466.04 & 1818.85 \\
\hline $120 \mathrm{~cm} \times(100 \%$ faba bean $+33 \%$ onion $)$ & 5700 & 4710 & 8362.0 & 7755.2 & 14062.0 & 12465.2 & 2901.68 & 2572.18 \\
\hline $120 \mathrm{~cm} \times(100 \%$ faba bean $+41 \%$ onion $)$ & 6255 & 4890 & 8140.0 & 6808.0 & 14395.0 & 11698.0 & 3060.35 & 1525.82 \\
\hline $120 \mathrm{~cm} \times(100 \%$ faba bean $+55 \%$ onion $)$ & 8475 & 7095 & 8066.0 & 8066.0 & 16541.0 & 15161.0 & 4554.76 & 4013.20 \\
\hline F - test & $* *$ & $*$ & $* *$ & $* *$ & $* *$ & $* *$ & $* *$ & $* *$ \\
\hline \multirow[t]{2}{*}{ L.S.D } & 143 & 116 & 43.4 & 32.6 & 136.8 & 127.1 & 203.57 & 193.94 \\
\hline & 211 & --- & 94.3 & 97.9 & 187.5 & 182.3 & 298.72 & 315.81 \\
\hline
\end{tabular}




\section{CONCLUSION}

Increasing plant density of onion under intercropping culture from 27 to $55 \%$ of ridge width $120 \mathrm{~cm}$ achieved the highest bulbs yield and economic return. This treatment produced 10.90 ardab of faba bean seeds +9.93 ton of bulbs/fad.

\section{REFERENCES}

1. Abd El-Rahman Rehab A.M.(2014). Effect of plant population and distribution on yield and yield components of five faba bean genotypes. J. Plant Production, Mansoura Univ., 5 (11): $1965-1972$.

2. Abou-Keriasha, M.A., Nadia M.A. Eisa and N.M.H. El-Wakil(2013). Effects of intercropping faba bean on onion and wheat with or without inoculated bacteria on yields of the three crops. Egypt. J. Agron., 35 (2): 169 - 182.

3. Ageeb O.A.A. (1983). Effect of row and plant spacing on the seed yield of faba bean. ICARDA/IFAD Nile Valley Project on faba bean, 13- 17 September 1984, Cairo

4. Almeida F.A.C., L. López-Bellido, M. Fuentes and J.E. Castillo (1995). Effect of plant density on growth and yield of faba bean (Vicia faba L.) in Mediterranean conditions. In: AEP (Ed.), Proc. Second Eur. Conf. on Grain Legumes, 9-13 July, Copenhagen, Denmark, p. 167

5. Balraj S.R., S. Sharma and Y. Kumar (1998). Effect of bulb spacing and nitrogen levels on growth and seed yield of onion (Allium cepa L.). Seed Res. Jaipur, India., 180 - 182.

6. Banik P., A. Midya, B.K. Sarkar and S.S. Ghose (2006). Wheat and chickpea intercropping systems in an additive series experiment: advantages and weed smothering. Eur. J. Agron., 24: 325 - 332.

7. Bianchi A.A. (1979). Results of three years of experimental trials on the cultural techniques of the horse bean for seeding (Vicia faba minor Beck). 2- Plant densities and distance between the rows. Riv Agron., 13: $201-206$.

8. Bulletin of Statistical Cost Production and Net Return(2015). Winter Field Crops and Vegetables and Fruit, Agriculture Statistics and Economic Sector, Ministry of Egyptian Agriculture and Land Reclamation, Part (1), February 2015, Egypt.

9. Caballero R.(1987). The effect of plant population and row width on seed yields and yields components of field beans. Res. Dev. Agric., 4: 147 - 150.

10. Dorcas A.O.A., M.D. Magaji, A. Singh, R. Ibrahim and Y. Siddiqu (2012). Irrigation scheduling for onion (Allium cepa L.) at various plant densities in a Semi-Arid environment. UMT $11^{\text {th }}$ Int. Annu Sym. on Sustain. Sci. and Management, Terengganu, Malaysia.

11. El-Hawary N.A., M.M. El-Mihi, I.O. Metwally, M.A. El-Masry and A.S. Kamel (1991). Influence of intercropping patterns and foliar spray with micronutrients on growth and yield of faba bean and onion. Ann. Agric. Sci., Moshtohor, 29 (2): 669 - 679.

12. El Kalla S.E., A.K. Mostafa, A.A. Leilah and A.A. Rokia. (1999). Mineral and biophosphatic fertilization for intercropped faba bean and onion. Egypt. J. Agric. Res., 77: 253-271.

13. Ghobashi A.A. and M.A.T. El-Aweel (1996). A preliminary study on intercropping onion, faba bean and chickpea in the Sultanate Oman. J. Agric. Sci., 21(7): 2463 - 2472. 
14. Javadzadeh A., A. Ghorbanihaghjo, S. Bonyadi, MR Rashidi, M Mesgari, N Rashtchizadeh and H. Argani (2009). Preventive effect of onion juice on selenite-induced experimental cataract. Ind. J. Ophthalmol., 57: 185 - 189.

15. Kantona R.A.L.L., R.G. Abbeyb, M.A. Hillac, N.D. Tabil.( 2003). Density affects plant development and yield of bulb onion (Allium cepa L.) in Northern Ghana. J. Veg. Crop Prod., 8(2): 15 - 25.

16. Kapczyńska A. (2013). Effect of plant spacing on the growth, flowering and bulb production of four lachenalia cultivars. South African Journal of Botany 88: 164-169.

17. Khalil S.K., A. Wahab, A. Rehman, F. Muhammad, S. Wahab, A.Z. Khan, M. Zubair, M.K. Shah, H. Khalil and R. Amin(2010). Density and planting date influence phonological development, assimilate partitioning and dry matter production of faba bean. Pak. J. Bot., 42(6): 3831 - 3838.

18. Khan M.A., M.K. Hasan, M.A.J. Miah, M.M. Alam and A.S.M.H. Masum (2003). Effect of plant spacing on the growth and yield of different cultivars of onion. Pak. J. Bio. Sci., 6(18): $1582-1585$.

19. López-Bellido F.J., L. López-Bellido and R.J. López- Bellido (2005). Competition, growth and yield of faba bean (Vicia faba L.). Eur. J. Agron., 23: $359-378$.

20. Loss S.P., K.H.M. Siddique, L.D. Martin and A. Crombie (1998). Responses of faba bean (Vicia faba L.) to sowing rate in South-western Australia. Part II: canopy development, radiation absorption and dry matter partitioning. Aust. J. Agric. Res., 49: 999 - 1008.

21. Mathews P.W., E.L. Armstrong, C.J. Lisle, I.D. Menz, P.L. Shephard and B.C. Armstrong (2008). The effect of faba bean plant population on yield, seed quality and plant architecture under irrigation in southern NSW. Proc. $14^{\text {th }}$ Aust. Agron. Conf., September, Adelaide South Australia. www.agronomy.org.au.

22. Mead R. and R.W. Willey (1980). The concept of a land equivalent ratio and advantages in yields from intercropping. Exp. Agric., 16: $217-228$.

23. Pilbeam C.J., P.D. Hebblethwaite, H.E. Ricketts and T.E. Nyongesa (1991). Effects of plant population density on determinate and indeterminate forms of winter field beans (Vicia faba). Part 1: Yield and yield components. J. Agric. Sci., 116: 375 - 383.

24. Ragab A.A., A.T. Emanand and S.M. Abd El-Rasoul (2010). A comparison between traditional and recent bioinocula on growth and productivity of faba bean (Vicia faba L.) grown in calcareous soil. Int. J. Academic Res., 2(4): 245 - 253.

25. Saud S., Yajun C., Razaq M., Luqman M., Fahad S., Abdullah M. and Sadiq A.(2013). Effect of potash levels and row spacings on onion yield. J. Bio. Agric. and Healthcare, 3(16): $118-127$.

26. Smittle, D.A. (1993). Onion Production in the Tropics: Effect of Environment on Onion Growth and Development Sweet Onion Production in the Tropics. Export Industry Technology Support Project (Agricultural Component), Assignment No. ST-115.

27. Snedecor, G.W. and W.G. Cochran (1973). Statistical Methods. $6^{\text {th }}$ Ed. The Iowa State Univ. Press. Iowa, USA.

28. USDA. (2005). USDA Economics, Statistics and Market Information System, World drybulb onions: Production, 1961-2005 (Albert R. Mann Library, Cornell University) 